\title{
PEMBELAJARAN KIMIA MENGGUNAKAN METODE RECIPROCAL TEACHING (RT) DAN PROBLEM POSING (PP) DITINJAU DARI KEMAMPUAN BERPIKIR KRITIS DAN KEMAMPUAN VERBAL
}

\author{
Arista Novia Dewi ${ }^{1}$, Ashadi $^{2}$, Sri Mulyani ${ }^{3}$ \\ ${ }^{1}$ Program Studi Magister Pendidikan Sains FKIP Universitas Sebelas Maret \\ Surakarta, 57126, Indonesia \\ are_ista03@yahoo.com \\ ${ }^{2}$ Program Studi Magister Pendidikan Sains FKIP Universitas Sebelas Maret \\ Surakarta, 57126, Indonesia \\ ashadi_uns@yahoo.com \\ ${ }^{3}$ Program Studi Magister Pendidikan Sains FKIP Universitas Sebelas Maret \\ Surakarta, 57126, Indonesia \\ srimulyaniuns@gmail.com
}

\begin{abstract}
Abstrak
Tujuan penelitian ini adalah untuk mengetahui pengaruh pembelajaran kimia menggunakan metode $P P$ dan $R T$, kemampuan berpikir kritis, kemampuan verbal dan interaksinya terhadap prestasi belajar. Penelitian ini menggunakan metode eksperimen, populasinya terdiri dari semua siswa kelas XI IPA SMA N 1 Nguter. Pengambilan sampel menggunakan teknik cluster random sampling. Kelas XI IPA 1 diberikan pembelajaran dengan metode $R T$, sedangkan XI IPA 2 diberikan pembelajaran dengan metode $P P$. Data dikumpulkan dengan tes untuk prestasi kognitif, kemampuan verbal dan kemampuan berpikir kritis, bservasi untuk prestasi belajar psikomotor serta angket untuk prestasi belajar afektif. Teknik analisis data menggunakan analisis non parametrik Kruskal Wallis. Berdasarkan hasil penelitian diperoleh kesimpulan sebagai berikut: (1) Ada pengaruh pembelajaran kimia menggunakan metode Probem Posing dan $R T$ baik prestasi ranah kognitif, afektif dan psikomotor. (2) Ada pengaruh kemampuan berpikir kritis terhadap prestasi afektif, tetapi tidak ada pengaruh terhadap prestasi kognitif dan psikomotor. (3) Ada pengaruh kemampuan verbal terhadap prestasi kognitif dan psikomotor, tetapi tidak ada pengaruh terhadap prestasi afektif. (4) Ada interaksi antara metode pembelajaran $P P$ dan $R T$ dengan kemampuan berpikir kritis tinggi dan rendah terhadap prestasi kognitif, afektif, dan pikomotor. (5) Ada interaksi antara metode pembelajaran $P P$ dan $R T$ dengan kemampuan verbal tinggi, rendah terhadap prestasi kognitif, afektif maupun psikomotor. (6) Ada interaksi antara kemampuan verbal dan kemampuan berpikir kritis terhadap prestasi kognitif dan afektif. Tetapi, tidak ada interksi pada prestasi psikomotor. (7) Ada interaksi antara metode $P P$ dan $R T$ dengan kemampuan berpikir kritis dan kemampuan verbal terhadap prestasi kognitif, afektif dan psikomotor.
\end{abstract}

Kata Kunci: metode Problem Posing (PP), Reciprocal Teaching (RT), Kemampuan Berpikir Kritis, Kemampuan Verbal

\section{Pendahuluan}

Pendidikan adalah salah satu cermin suksesnya suatu bangsa. Peningkatan mutu pendidikan sangat berkaitan dengan proses pembelajaran. Oleh karena itu tujuan pembelajaran hendaknya disesuaikan dengan UUSPN No 20 tahun 2003 yaitu untuk mewujudkan suasana belajar dan proses pembelajaran yang terencana dan terarah Salah satu upaya peningkatan kualitas pendidikan adalah mengimplementasikan Kurikulum 
Tingkat Satuan Pendidikan (KTSP). Dalam KTSP guru sebagai fasilitator dan lebih diberi kebebasan untuk memilih batasan materi yang dibutuhkan siswa serta merencanakan pembelajaran sesuai dengan lingkungan dan kondisi siswa dan sekolah. Namun secara umum masih banyak sekolah yang menggunakan Teacher Center Learning (TCL). Salah satunya adalah SMA N 1 Nguter khususnya mata pelajaran kimia.

Salah satu materi kimia kelas XI adalah termokimia. Karakteristik materi termokimia antara lain (1) bersifat abstrak misalnya pada perubahan entalpi berdasarkan energi ikat (energi disosiasi), hukum Hess, dan berdasarkan entalpi pembentukan dari beberapa senyawa kimia, (2) bersifat laboratorium yaitu pada reaksi endoterm dan eksoterm serta kalorimeter, (3) bersifat konsep yaitu perbedaan kalor dan perubahan entalpi, konsep reaksi endoterm dan eksotem, (4) bersifat logika-matematis yaitu banyak perhitungan untuk menghitung $\Delta \mathrm{H}$ berdasarkan informasi tertentu. Berdasarkan karakteristik tersebut maka tidak menutup kemungkinan terjadi kesulitan siswa dalam mengikuti proses pembelajaran. Hal ini terlihat dari hasil UH SMA N 1 Nguter Th. Pelajaran 2012/2013 seperti yang tercantum pada tabel 1 .

Tabel 1: Nilai Rata-Rata UH Termokimia

\begin{tabular}{cccccc}
\hline No & $\begin{array}{c}\text { Kelas } \\
\text { XI } \\
\text { IPA }\end{array}$ & $\begin{array}{c}\text { KK } \\
\text { M }\end{array}$ & $\begin{array}{c}\text { Nilai } \\
\text { Rata }^{2}\end{array}$ & $\begin{array}{r}\text { \% siswa } \\
<\text { KKM }\end{array}$ & $\begin{array}{c}\text { \% siswa } \\
>\text { KKM }\end{array}$ \\
\hline 1 & 1 & 70 & 56,8 & $66,67 \%$ & $33,33 \%$ \\
2 & 2 & 70 & 62,8 & $52,64 \%$ & $47,36 \%$ \\
3 & 3 & 70 & 61,0 & $70,26 \%$ & $29,74 \%$ \\
\hline
\end{tabular}

Tabel 1 menunjukkan bahwa $>50 \%$ siswa masih di bawah KKM. Berdasar hasil wawancara dan angket pada siswa, juga menunjukkan $70,27 \%$ menggangap materi termokimia adalah materi sulit dibandingkan dengan materi kimia yang lain. Berdasarkan karakteristik materi tersebut, maka kemungkinan penerapan metode RT dan PP sesuai dengan materi termokimia.

Menurut Palinscar dan Brown (1989: 115) Metode RT adalah metode konstruktivisme yang mengacu pada kegiatan yang terjadi dalam bentuk dialog antara guru dan siswa mengenai suatu pokok bahasan. Metode ini merupakan strategi pembelajaran untuk memenuhi kebutuhan siswa dengan kemampuan decoding kuat tetapi pemahaman yang rendah (Mcallum, 2014). Tahapan pelaksanaan metode RT meliputi empat strategi yaitu (1) tahap persiapan,(2) Tahap pemecahan masalah meliputi: meringkas, mengajukan pertanyaan, mengklarifikasi dan memprediksi, (3) persentasi, (4) kesimpulan.

Beberapa penelitian antara lain penelitian Darsono (2015) menunjukkan bahwa penerapan RT memberikan dampak positif pada prestasi siswa pada mata pelajaran persamaan garis lurus kelas IX dan respon siswa menunjukkan sebagian besar siswa ingin menghadiri kelas. Penelitian Hattie dan Westera (Mcallum, 2014) menunjukkan dari 38 studi internasional, metode RT sebagai strategi tertinggi ketiga dari 49 strategi pembelajaran, menunjukkan perbaikan yang signifikan pada kemampuan siswa, pemahaman membaca dan kemampuan metakognitif.

Menurut Ann Brown (Afifah, 2012) Kelebihan dari metode RT adalah melatih kemandirian siswa mengembangkan kreativitas siswa, memupuk kerjasama antar siswa, menumbuhkan bakat berbicara dan mengembangkan sikap, siswa lebih memperhatikan pelajaran karena menghayati sendiri, memupuk keberanian, melatih siswa untuk menganalisis masalah dan mengambil kesimpulan Melalui metode ini diharapkan memberikan siswa kesempatan untuk terbiasa menganalisis, berargumen tentang ide yang dimiliki dan mengembangkan daya pikir kreatif siswa misalnya dalam pemahamn soal, menjawab dan membuat soal, serta meningkatkan kemampuan bernalar. Sedangkan, kelemahan metode RT 
adalah keaktifan siswa, baik bertanya maupun berpendapat lebih didominasi siswa yang percaya diri. Kemudian, sebagian siswa tidak fokus terhadap pelajaran tetapi fokus pada teman yang sedang menjelaskan materi. Jadi, Melalui metode ini diharapkan memberikan kesempatan siswa untuk terbiasa mengeluarkan ide gagasan dan mengembangkan penalarnya dari situasi yang diberikan, dan keberhasilan siswa dapat dilihat bagaimana kemampuan menjelaskan kembali pengetahuanya yang diperoleh (Afandi, 2012).

PP (Nurlaila, Suparmi, \& Sunarno, 2013) adalah suatu pembelajaran dengan cara siswa diminta untuk merumuskan, membentuk dan mengajukan pertanyaan atau soal dari situsi yang disediakan, situasi dapat berupa gambar, cerita, atau informasi lain yang berkaitan dengan materi pelajaran, dan selanjutnya siswa sendiri yang harus mendesain cara penyelesaiannya. PP (Pittalis, Christou, Mousoulides, \& Pitta-Pantazi, 2004) adalah kerakteristik pembelajaran matematika. Hal ini sesuai dengan karakteritik dari materi Termokimia yang banyak menggunakan konsep matematik. Sehingga, Fungsi guru adalah memotivasi siswa agar mau menerima tantangan dan membimbing siswa dalam proses pemecahannya.

Beberapa penelitian (Rosli,

Capraro, \& Capraro, 2014) menunjukkan bahwa PP memberikan manfaat yang cukup besar untuk prestasi matematika, ketrampilan pemecahan masalah, serta sikap terhadap matematika. Penelitian Nurlaila (2013) menunjukkan bahwa penerapan metode PP memberikan nilai yang lebih tinggi pada prestasi kognitif, afektif, dan psikomotor daripada metode Problem Solving.

Kelebihan metode PP adalah memberi penguatan pada konsep yang diterima atau memperkaya konsep dasar, memberi keleluasaan kepada siswa untuk menggali pengetahuan dalam mencari dan menyusun soal sesuai dengan pengetahuannya, dan mampu melatih siswa meningkatkan kemandirian dalam belajar. Sedangkan kekurangan metode PP adalah tidak semua siswa memiliki kemampuan untuk menguasai konsep dalam waktu yang singkat, pertanyaan yang dibuat oleh siswa tidak semuanya bersifat menantang, dan pelaksanaannya memerlukan waktu yang relatif lama.

Selain metode pembelajaran, faktor internal juga berpengaruh terhadap prestasi belajar. Faktor internal tersbut anta lain kemampuan berpikir kritis dan kemampuan verbal.

Berpikir kritis adalah sebuah proses berpikir reflektif dan fokus terhadap pemutusan apa yang harus dipercaya dan dilakukan (Ennis, 2011). Kemampuan berpikir kritis menurut John Dewey (Fisher, 2009:2) adalah sebuah proses berpikir yang reflektif dan aktif, dimana seseorang memikirkan berbagai hal secara lebih mendalam, mengajukan pertanyaan, dan menemukan informasi yang relevan dibanding menerima berbagai hal dari orang lain secara pasif. Sedangkan kemampuan verbal Menurut Winkel (1991: 99), adalah kemampuan yang dimiliki seseorang dalam menuangkan pengetahuan dan pengalaman yang dimiliki dalam bentuk bahasa yang memadai, sehingga dapat dikomunikasikan kepada orang lain.

Kedua faktor internal tersebut sejalan dengan penerapan kedua metode. Kedua metode dibentuk kelompok, sehingga kemampuan verbal dibutuhkan untuk berinteraksi antar siswa dan siswa dengan guru. Kemudian kemampuan berpikir kritis digunakan dalam menyelesaikan masalah baik dalam pengajuan soal pada PP maupun membuat bertanyaan dan memprediksi pada RT.

Tujuan penelitian ini adalah untuk mengetahuai 1) Pengaruh pembelajaran 
kimia dengan menggunakan metode RT dan PP terhadap prestasi belajar. 2) Pengaruh kemampuan berpikir kritis prestasi belajar siswa. 3) Pengaruh kemampuan verbal terhadap prestasi belajar siswa. 4) Interaksi antara metode RT dan PP dengan Kemampuan berpikir kritis siswa terhadap prestasi belajar siswa. 5) Interaksi antara metode RT dan PP dengan kemampuan verbal terhadap prestasi belajar siswa. 6) Interaksi antara kemampuan berpikir kritis dan kemampuan verbal siswa terhadap prestasi belajar siswa. 7) Interaksi antara antara metode RT, PP, kemampuan berpikir kritis dan kemampuan verbal siswa terhadap prestasi belajar siswa.

\section{Metode Penelitian}

Penelitian ini dilaksanakan di SMA N 1 Nguter Sukoharjo tahun pelajaran 2013/2014 menggunakan penelitian eksperimen dengan dua sampel. Kelas pertama (XI IPA 1) dengan metode RT dan kelas kedua (XI IPA 2) dengan metode PP. Desain faktorial penelitian adalah $2 \times 2 \times 2$. Pengambilan sampel dengan cluster random sampling.

Variabel bebas yang digunakan adalah metode. Variabel moderator yang digunakan adalah kemampuan verbal dan berpikir kritis, dan variabel terikatnya adalah prestasi kognitif, afektif, dan psikomotor. Teknik pengumpulan data meliputi metode tes, angket, dan observasi. Instrumen penelitian meliputi silabus, RPP, LKS, tes kemampuan verbal, tes kemampuan berpikir kritis, tes prestassi kognitif, angket afektif, lembar observasi penilaian psikomotor.Uji coba instrumen meliputi uji validitas, dan uji reliabilitas. Sedangkan, teknik uji data penelitian menggunakan uji normalitas dan homogenitas, serta uji hipotesis menggunakan uji Kruskal-Wallis

\section{Hasil Penelitian dan Pembahasan}

Data yang diperoleh pada penelitian ini adalah data prestasi kognitif, afektif, psikomotor, kemampuan berpikir kritis dan kemampuan verbal. Deskripsi data tersebut disajikan pada tabel 1 .

Tabel 1: Data prestasi kognitif, afektif dan psikomotor.

\begin{tabular}{|c|c|c|c|c|c|c|}
\hline \multirow{2}{*}{$\begin{array}{l}\text { metode } \\
\text { Pembe- } \\
\text { lajaran }\end{array}$} & \multicolumn{2}{|c|}{ Kemampuan } & \multirow{2}{*}{$\begin{array}{l}\text { Jum- } \\
\text { lah } \\
\text { Siswa }\end{array}$} & \multirow[b]{2}{*}{$\begin{array}{l}\text { Kog- } \\
\text { nitif }\end{array}$} & \multirow[b]{2}{*}{ Afektif } & \multirow[b]{2}{*}{$\begin{array}{l}\text { Psiko- } \\
\text { notor }\end{array}$} \\
\hline & $\begin{array}{c}\text { Berpikir } \\
\text { Kritis }\end{array}$ & verbal & & & & \\
\hline \multirow{4}{*}{$\begin{array}{c}\text { Metode } \\
\text { RT }\end{array}$} & \multirow{2}{*}{ tinggi } & tinggi & 13 & 76,62 & 78,83 & 82,31 \\
\hline & & rendah & 8 & 69 & 77,81 & 80,31 \\
\hline & \multirow{2}{*}{ rendah } & tinggi & 5 & 71,2 & 75,75 & 81,02 \\
\hline & & rendah & 8 & 65 & 73,77 & 80 \\
\hline \multirow{4}{*}{$\begin{array}{c}\text { Metode } \\
\text { PP }\end{array}$} & \multirow{2}{*}{ tinggi } & tinggi & 8 & 85,5 & 74,38 & 78,44 \\
\hline & & rendah & 7 & 73,75 & 73,75 & 78,21 \\
\hline & \multirow{2}{*}{ rendah } & tinggi & 11 & 73,45 & 68,98 & 82,05 \\
\hline & & rendah & 10 & 79,4 & 72,63 & 78,5 \\
\hline
\end{tabular}

Tabel 1. Menunjukkan bahwa nilai kognitif yang tertinggi adalah menggunakan metode PP dengan siswa berkemampuan verba dan berpikir kritis tinggi yaitu 85,5. Sedangkan nilai terendah adalah menggunakan metode RT dengan kemampuan siswa berpikir kritis dan verbal yang rendah, yaitu 65 Pada prestasi afektif diperoleh nilai tertinggi pada metode RT dengan siswa berkemampuan verbal dan berpikir kritis yang tinggi yaitu 78,85. Sedangkan, nilai terendah pada prestasi afektif pada metode PP dengan siswa berkemampuan verbal tinggi dan kemampuan berpikir kritis rendah yaitu 68,89. Pada prestasi psikomotor nilai tertinggi terdapat pada metode RT dengan siswa berkemampuan verbal dan berpikir kritis tinggi yaitu 82,31. Sedangkan, prestasi psikomotor dengan nilai terendah terdapat pada metode PP dengan siswa berkemampuan verbal rendah dan kemampuan berpikir kritis tinggi yaitu 78,21 .

Berdasarkan hasil uji hipotesis dengan Kruskal-Wallis diperoleh data seperti yang disajikan pada tabel 2 . 
Tabel 2. Deskripsi data uji hipotesis

\begin{tabular}{lccc}
\hline Zaktor & $\begin{array}{c}\text { Signifikansi } \\
\text { prestasi } \\
\text { kognitif }\end{array}$ & $\begin{array}{c}\text { Signifikansi } \\
\text { Prestasi } \\
\text { Afektif }\end{array}$ & $\begin{array}{c}\text { Signifikansi } \\
\text { Prestasi } \\
\text { Psikomotor }\end{array}$ \\
\hline $\begin{array}{l}\text { Metode } \\
\text { Jembelajaran }\end{array}$ & 0,002 & 0,004 & 0,031 \\
\hline KBK & 0,102 & 0,007 & 0,971 \\
\hline KV & 0,032 & 0,864 & 0,022 \\
\hline Metode - BK & 0,002 & 0,005 & 0,020 \\
\hline Metode - KV & 0,001 & 0,012 & 0,018 \\
\hline KBK - KV & 0,017 & 0,040 & 0,111 \\
\hline Metode - & 0,001 & 0,027 & 0,020 \\
KBK - KV & & & \\
\hline Se KBK
\end{tabular}

Ket: $\mathrm{KBK}=$ kemampuan berpikir kritis

$\mathrm{KV}=$ kemampuan verbal

1. Pengaruh menggunakan metode RT dan PP terhadap prestasi belajar siswa

Hasil uji statistik (Tabel 2) non parametrik Kruskal-Wallis menunjukkan nilai signifikansi 0,002 terhadap prestasi belajar siswa pada ranah kognitif, 0,004 terhadap ranah afektif dan 0,031 terhadap ranah psikomotor. Dari hasil uji tersebut diperoleh nilai signifikansi $(\alpha)<5 \%$ hal ini menunjukkan bahwa Ho ditolak yang artinya terdapat pengaruh metode pembelajaran PP dan RT terhadap prestasi belajar siswa.

Berdasarkan rerata prestasi belajar siswa pada ranah kogitif menggunakan metode RT dan PP berturut-turut adalah 71,29 dan 77,33. Dari hasil nilai rerata kognitif menunjukkan bahwa prestasi siswa menggunakan metode PP lebih baik daripada dengan metode RT. Hal ini sesuai dengan penelitian Nurlaila (2013) dan steven (2014) yang menunjukkan bahwa metode PP menunjukkan nilai prestasi yang lebih tinggi daripada problem solving dan TAPPS. Selain itu menurut penelitian Rosli (2014) disebutkan bahwa metode PP memberikan manfaat yang cukup besar terhadap prestasi siswa, ketrampilan pemecahan masalah dan sikap terhadap matematika.

Prestasi kognitif siswa menggunkan metode PP lebih tnggi karena metode PP setelah siswa mendapatkan konsep siswa dituntut membuat pertanyaan sehingga terjadi penguatan konsep pada siswa, karena proses pengajuan masalah mendorong siswa untuk lebih aktif dalam belajar sehingga pada akhirnya meningkatkan penalaran dalam memahami situasi yang diberikan. selain itu pembelajaran juga terjadi lebih kondusif.

Siswa juga melakukan diskusi untuk memecahkan masalah yang sebelumnya soal telah ditukar dengan kelompok lain. Hal ini sesuai dengan pendapat Johnson et al (Nugroho \& Mulyani, 2014) yaitu belajar adalah suatu proses sosial (bercakap-cakap, berbicara, berdiskusi, dan bekerjasama), serta sesuai dengan teori kontruktivisme menurut Vygotsky. Yaitu, belajar hendaknya menekankan pada pentingnya keterlibatan siswa dalam suatu interaksi sosial untuk membangun bersama makna suatu pengetahuan sehingga akan muncul kerjasama secara aktif.

Berdasar karakteristik materi, rerata prestasi kognitif PP lebih tinggi dibandingkan dengan RT, karena PP lebih menekankan pada konsep matematika sehingga sangat mendukung untuk materi termokimia karena hampir semua materi termokimia menggunakan hitungan. Metode RT pembelajarannya sebenarnya lebih terbimbing namun dengan PP siswa lebih banyak pengajuan soal disertai penyelesaiannya sehingga siswa pada kelas ini lebih banyak tau variasi-variasi soal termokimia beserta cara penyelesainnya. Hal tersebut berkaitan dengan keunggulan dari PP.

Pada prestasi belajar ranah afektif dan psikomotor kelas PP memiliki rerata lebih tinggi dibandingkan kelas RT. Hal ini, menunjukkan metode PP lebih baik untuk meningkatkan keaktifan siswa dalam pemecahan masalah, meningkatkan minat, motivasi belajar, serta memberikan arah yang positif terhadap sikap, nilai, konsep diri dan moral. Hai ini sesuai dengan hasil 
penelitian dari Nurlaila (2013) yang menunjukkan bahwa $P P$ memberikan hasil yang lebih tinggi pada ranah prestasi afektif maupun psikomotor. Pada dasarnya kedua penggunaan metode dapat meningkatkan minat dan motivasi belajar siswa, namun berdasarkan hasil penelitian PP menunjukkan hasil yang lebih baik dibandingkan dengan RT. Begitu juga pada prestasi psikomotor karena, siswa memiliki minat, motivasi dan keaktifan yang lebih baik maka dimungkinkan dapat mendorong kinerja siswa untuk lebih terampil dalam menggunakan alat, lebih teliti serta hati-hati dalam praktikum.

2. Pengaruh kemampuan berpikir kritis tinggi dan rendah siswa terhadap prestasi siswa

Hasil uji statistik non parametrik Kruskal-Wallis menunjukkan nilai signifikansi 0,102 ranah kognitif, 0,007 ranah afektif, dan 0,971 ranah psikomotor. Dari hasil uji tersebut dapat disimpulkan bahwa tidak ada pengaruh kemampuan berpikir kritis tinggi dan rendah siswa terhadap prestasi siswa ranah kognitif dan psikomotor, tetapi ada pengaruh terhadap prestasi siswa pada ranah afektif.

Berpikir kritis adalah pemikiran reflektif dan masuk akal yang berfokus pada memutuskan apa yang harus dipercayai atau dilakukan (Ennis, 2011). Termokimia merupakan materi kimia yang menekankan pada konsep dan bersifat abstrak sehingga kemampuan berpikir kritis sangat diperlukan. Berdasar hasil perhitungan kemampuan berpikir kritis tinggi dan rendah pada ranah kognitif memiliki retara 76,28 dan 72,88. Dari hasil tersebut nilai prestasi siswa yang mempunyai kemampuan berpikir kritis tinggi lebih baik dari pada nilai siswa yang mempunyai kemampuan berpikir kritis rendah. Siswa dengan kemampuan berpikir kritis tinggi memiliki rasa ingin tahu yang lebih besar untuk belajar dan berusaha berpikir secara logis dalam rangka memecahkan masalah, dengan cara mencari sendiri pemecahan masalahnya atau dengan bertanya terhadap guru. Siswa yang memiliki kemampuan berpikir kritis tinggi dalam pengambilan keputusan siswa mencari informasi sebanyak-banyaknya dari sumber belajarnya. Selain itu siswa lebih dapat mengembangkan informasi yang sudah ada untuk memecahkan masalah seperti menyelesaian tes atau tugas dari guru. Penelitian (Thompson, 2011) menyebutkan bahwa kemampuan berpikir kritis memberikan kontribusi dalam pencapaian prestasi belajar yang maksimal. Siswa yang mempunyai kemampuan berpikir kritis tinggi akan terampil penalarannya. Tetapi karena perbedaan nilai antara siswa berkemampuan kritis tinggi dan berkemampuan kritis rendah kurang signifikan maka Ho diterima.

Hasil uji data prestasi afektif menunjukkan nilai rerata siswa dengan kemampuan kritis tinggi 76,63 dan siswa dengan kemampuan kritis rendah mempunyai rerata 72,18 . Hal ini disebabkan karena siswa dengan kemampuan berpikir kritis tinggi memiliki minat dan motifasi belajar yang lebih baik. Hasil peneli penelitian Thomson (2011) menunjukkan bahwa berpikir kritis dapat memberikan hasil yang baik pada perkembangan moral, sosial, kognitif, mental, serta perkembangan sains. Cheryl Perkins dan Elizabeth Murphy (Marsutji, Bakti, Sunarno, \& Suparmi, 2013) disimpulkan bahwa keterlibatan siswa yang mempunyai berpikir kritis tinggi dalam proses diskusi sangat efektif dan lebih aktif dalam mengungkapkan pendapatnya. Jadi, disimpulkan bahwa siswa yang mempunyai kemampuan berpikir kritis tinggi memperoleh mean prestasi afektif lebih tinggi dibanding dengan siswa yang mempunyai kemampuan berpikir kritis rendah. 
3. Pengaruh kemampuan verbal siswa terhadap prestasi belajar

Hasil uji non parametrik menggunakan uji Kruscal-Wallis menunjukkan nilai signifikansi 0,032 terhadap prestasi kognitif, 0,864 terhadap prestas afektif dan 0,022 terhadap prestasi ranah psikomotor. Berdasarkan hasil hitung tersebut dapat disimpulkan bahwa terdapat pengaruh kemampuan verbal tinggi dan rendah terhadap prestasi belajar ranah kognitif dan psikomotor, tetapi tidak ada pengaruh prestasi belajar pada ranah afektif.

Kemampuan verbal merupakan kemampuan seseorang untuk berinteraksi dengan teman sebaya maupun dengan sumber belajar (guru) untuk mengungkapkan ide, gagasan, pendapat dan pikiran yang ditunjukkan dengan komunikasi Dalam membangun pengetahuan di materi termokimia sangat memebutuhkan siswa aktif untuk berani bertanya, menjawab, dan berpendapat sehingga akan terjadi proses asimilasi dan akomodasi pengetahuan yang diperoleh. Sehingga siswa dengan kemampuan verbal tinggi akan mendapatkan nilai lebih baik daripada siswa berkemampuan verba rendah. Penelitian (Nurkholis, 2013) tes kemampuan verbal, menunjukkan ada pengaruh kemampuan verbal terhadap prestasi kognitif yaitu kemampuan verbal tinggi memiliki nilai yang lebih baik daripada siswa dengan kemampuan verbal rendah.

Pada penelitian ini, kemampuan verbal siswa diterapkan dalam pelaksanaan diskusi kelompok. Dimana di salah satu sintak di kedua metode pembelajaran yang digunakan melakukan kegiatan diskusi kelompok dan pelaksanaan praktikum. Menurut teori belajar Vygotsky, interaksi antar teman atau interaksi dengan lingkungan sosial di sekitarnya dapat memberikan pengaruh yang positif terhadap prestasi belajar siswa. Hal ini sesuai dengan hasil penelitian yang telah dilakukan yang menunjukkan bahwa kemampuan verbal dapat meningkatkan prestasi kognitif siswa. dimana rerata prestasi kognitif siswa yang mempunyai kemampuan verbal tinggi dan rendah berturut-turut adalah 76,86 dan 72,12.

Berdasarkan rerata prestasi afektif, siswa yang mempunyai kemampuan verbal tinggi dan rendah adalah 74,52 dan 74,40. Hal ini dimungkinkan karena perbedaan rerata antara siswa dengan kemampuan verbal tinggi dan rendah kurang signifikan, dimungkinkan juga siswa yang memiliki minat serta motivasi belajar yang tinggi, memiliki konsep diri, nilai dan moral yang baik belum tentu memiliki kemampuan verbal tinggi pula.Pada prestasi psikomotor menunjukkan bahwa siswa yang dapat berinteraksi lebih baik (verbal tinggi) dengan anggota kelompokknya mempunyai prestasi psikomotoor yang lebih baik.

4. interaksi antara metode pembelajaran dengan kemampuan berpikir kritis terhadap prestasi belajar

Berdasarkan hasil uji non parametrik Kruskal-Wallis diproleh nilai signifikansi 0,002 untuk prestasi kognitif, 0,005 prestasi afektif dan 0,020 untuk prestasi psikomotor. Dari hasil uji tersebut menunjukkan bahwa nilai signifikansi $<0,05$ artinya hasil tersebut menunjukkan bahwa terdapat interaksi antara metode belajar $P P$ dan $R T$ dengan kemampuan berpikir kritis terhadap prestasi kognitif, afektif, dan psikomotor siswa.

Berdasarkan nilai rata-rata prestasi kognitif penerapan metode pembelajaran $P P$ terhadap kemampuan berpikir kritis tinggi dan rendah adalah 79,87 dan 76,29. Sedangkan penerapan metode pembelajaran $R T$ adalah 73,71 dan 67,38. Dari hasil tersebut menunjukkan bahwa penerapan metode $P P$ lebih baik pada siswa yang memiliki kemampuan berpikir kritis tinggi 
INKUIRI: Jurnal Pendidikan IPA

Vol. 8, No. 1, 2019 (hal 1-11)

https://jurnal.uns.ac.id/inkuiri

daripada dengan metode $R T$. Hal ini dikarenakan kemampuan berpikir kritis merupakan salah satu faktor internal siswa tentang aktifitas berpikir tingkat tinggi. Dalam metode $P P$ siswa diberikan kesempatan untuk mengajukan soal atau memberian pertanyaan. Kemudian, ketika siswa selesai membuat soal, siswa dituntut untuk memahami soal dengan baik dan menyelesaikan. Melalui pemberian tugas inilah siswa akan berusaha untuk dapat membuat perencanaan penyelesaian berupa pembuatan soal untuk kemudian menyelesaikannya.

Nilai rata-rata prestasi afektif siswa yang belajar menggunakan metode PP dengan kemampuan berpikir kritis tinggi dan rendah terhadap prestasi afektif 74,$09 ; 70,72$ dan prestasi psikomotor 78,33; 80,36. Hal ini menunjukkan bahwa kinerja siswa yang berkemampuan berpikir kritis tinggi belum tentu memiliki kinerja yang lebih baik pula. Sedangkan nilai rata-rata siswa menggunakan metode RT dengan kemampuan berpikir kritis tinggi dan rendah terhadap prestasi afektif 78,44 ; 74,53 dan prestasi psikomotor 81,55; 80,39 . Hal ini dimungkinkan karena siswa yang berkemampuan kritis tinggi memiliki minat dan motivasi belajar yang baik serta memberikan arah yang positif terhadap sikap, nilai, konsep diri, moral dan kepercayaan diri.

5. interaksi antara penerapan metode pembelajaran dengan kemampuan verbal siswa terhadap prestasi belajar

Berdasarkan hasil uji non parametrik dengan Kruskal Wallis diperoleh nilai signifikansi pada prestasi siswa ranah kognitif, afektif dan psikomotor berturut-turut adalah 0,001 ; 0,012; dan 0,018. Nilai signifikansi tersebut $<0,05$ sehingga Ho ditolak. Artinya terdapat interaksi antara metode dengan kemampuan verbal siswa terhadap prestasi belajar siswa yang meliputi prestasi kognitif, afektif dan psikomotor.
P-ISSN: 2252-7893

E-ISSN: 2615-7489

DOI: 10.20961/inkuiri.v8i1.31768

Tabel 3. Diskripsi data kemampuan verbal dengan metode pembelajaran terhadap prestasi

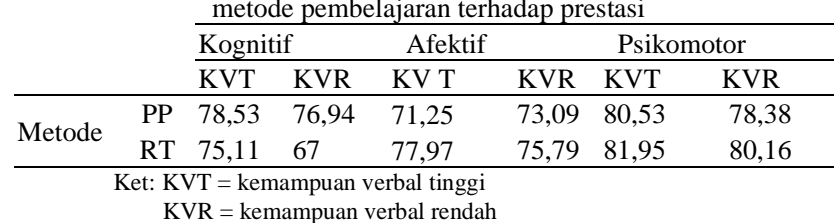

Hasil uji statistik data prestasi kognitif, afektif, dan psikomotor menunjukkan ada interaksi antara pengunakan metode pembelajaran dengan kemampuan verbal tinggi dan rendah terhadap prestasi siswa. Hal ini dimungkinkan karena melalui metode RT siswa mengalami kesulitan dalam memahami bacaan, kalimat serta menganalisis soal-soal yang telah diberikan. Melalui metode PP siswa dengan kemampuan verbal tinggi dapat menyampaikan materi atau informasi yang mereka dapat kepada teman sebayanya menggunakan kalimat yang mereka mudah pahami, sedangkan siswa yang berkemampuan rendah akan dapat bekerja secara kooperatif dengan temannya. Sehingga dapat mencapai tingkat kemampuan yang lebih tinggi. Metode PP juga memberikan keleluasaan kepada siswa untuk menggali pengetahuan dalam mencari informasi dari berbagai sumber belajar dan menyusun soal sesuai dengan pengetahuannya.

6. Iteraksi antara kemampuan berpikir kritis dengan kemampuan verbal terhadap prestasi kognitif

Hasil uji non parametrik KruskalWallis menunjukkan nilai signifikansi prestasi kognitif sebesar 0,017 (Ho ditolak), prestasi afektif sebesar 0,040 (Ho ditolak) dan prestasi psikomotor sebesar 0,111 (Ho diterima). Berdasarkan hasil uji menunjukkan bahwa terdapat interaksi antara kemampuan verbal dengan kemampuan berpikir kritis terhadap prestasi kognitif, afektif, tetapi tidak ada interaksi terhadap prestasi spikomotor. Hai ini dikarenakan, berdasar karakteristik kemampuan verbal sangat diperlukan siswa dalam meringkas materi, 
berdiskusi dan menyampaikan hasil diskusi di depan kelas dan teman yang lain sebagai listener, serta menyusun kesimpulan. Begitu pula dengan kemampuan berfkir kritis, sangat diperlukan dalam membuat pertanyaan dan memecahkan masalah yang telah disediaan.

Sedangkan, Kemampuan verbal dan kemampuan berpikir kritis tidak terdapat interaksi pada prestasi psikomotor, tidak terdapatnya interaksi ini dimungkinkan ketrampilan siswa dalam melakukan praktikum masih kurang tereksplor dan siswa yang memiliki kemampuan verbal dan kemampuan berpikir kritis tinggi belum tentu lebih baik dengan siswa yang dikategorikan dalam kemampuan rendah. Selain itu tidak adanya interaksi pada prestasi psikomotor dimungkinkan karena dipengaruhi faktor dari luar.

7. Interaksi antara metode pembelajaran, kemampuan verbal dan kemampuan berpikir kritis terhadap prestasi

Hasil hipotesis ketujuh berdasarkan hasil uji non parametrik Kruscal-Wallis tentang interaksi antara metode pembelajaran $R T$ dan $P P$ dengan kemampuan berpikir kritis dan kemampuan verbal terhadap prestasi belajar siswa ranah kognitif, afektif, dan psikomotor menunjukkan hasil nilai signifikansi terhadap prestasi kognitif sebesar 0,001 , signifikansi terhadap prestasi belajar afektif sebesar 0,027 , dan nilai signifikansi terhadap prestasi belajar spikomotor sebesar 0,020 . Hasil tersebut menunjukkan bahwa Ho ditolak untuk ketiga ranah prestasi pembelajaran. Artinya terdapat interaksi antara metode pembelajaran $P P$ dan $R T$, kemampuan berpikir kritis dan kemampuan verbal terhadap prestasi kognitif, afektif, dan psikomotor.

Dari hasil menunjukkan penerapan metode pembelajaran, kemampuan berpikir kritis dan kemampuan verbal saling berinteraksi terhadap prestasi kognitif siswa. Selain itu, kemampuan berpikir kritis rendah dan kemampuan verbal rendah dapat meningkatkan prestasi kognitif siswa selama dalam pembelajaran, kedua kemampuan tersebut secara terusmenerus dilatih untuk memecahkan masalah. hal ini terlihat bahwa nilai rerata prestasi kemampuan verbal dan kemampuan berpikir kritis rendah lebih tinggi dibandingkan dengan kemampuan berpikir kritis tinggi dan kemampuan verbal rendah, serta lebih tinggi dari siswa dengan kemampuan berpikir kritis rendah dan kemampuan verbal tinggi pada pembelajaran menggunakan $P P$.

Pada prestasi belajar siswa ranah afektif dan psikomotor, interaksi antara metode pembelajaran, kemampuan berpikir kritis dan kemampuan verbal dapat meningkatkan prestasi belajar siswa pada prestasi afektif dan psikomotor. Hal ini disebabkan karena sintak dalam kedua metode pembelajaran lebih banyak menggunakan diskusi. Sehingga mampu memberikan pengaruh yang positif terhadap minat, motivasi, dan konsep diri. Jika siswa minat dan motivasinya sudah baik maka dimungkinkan dalam melakukan kegiatan praktikum, pengamatan dan pengambilan kesimpulan secara bersama-sama dapat membantu mengkontruksikan atau membentuk pengatahuan siswa.

\section{Kesimpulan dan Rekomendasi}

1) Ada pengaruh penggunaan metode pembelajaran PP dan RT terhadap prestasi kognitif, afektif, dan psikomotor pada materi termokimia. Penerapan metode PP memberikan rerata nilai yang lebih baik pada prestasi kognitif tetapi tidak pada prestasi afektif dan psikomotor. 2) Ada pengaruh kemampuan berpikir kritis tinggi dan rendah terhadap prestasi afektif siswa, namun tidak ada pengaruh terhadap prestasi belajar kognitif dan psikomotor 
siswa pada materi termokimia. 3) Ada pengaruh kemampuan verbal tinggi dan rendah terhadap prestasi kognitif dan psikomotor siswa, namun tidak ada pengaruh terhadap prestasi afektif siswa pada materi pokok termokimia, 4) Ada interaksi antara metode pembelajaran PP dan RT dengan kemampuan berpikir kritis tinggi dan rendah terhadap prestasi kognitif, afektif, dan psikomotor siswa pada materi pokok termokimia, 5)Ada interaksi antara metode pembelajaran PP dan RT dengan kemampuan verbal tinggi, rendah terhadap prestasi kognitif, afektif, dan psikomotor siswa pada materi pokok termokimia. 6.Ada interaksi antara kemampuan verbal dan kemampuan berpikir kritis terhadap prestasi kognitif, dan afektif siswa. Namun, tidak terdapat interaksi antara kemampuan verbal dan kemampuan berpikir kritis siswa terhadap prestasi psikomotor pada materi pokok termokimia. 7. Ada interaksi antara metode pembelajaran PP dan RT dengan kemampuan berpikir kritis dan kemampuan verbal siswa terhadap prestasi kognitif, afektif, dan psikomotor siswa pada materi pokok termokimia. Implikasi Praktis yang dapat dikemukakan berdasar kesimpulan peneliti antara lain: 1. Metode pembelajaran PP dan RT dapat diterapkan pada pembelajaran kimia khususnya pada materi termokimia sehingga mempermudah siswa dalam mempelajari dan menguasai materi tersebut. Dari penelitian ini penerapan metode PP dapat memberikan prestasi yang lebih baik.. 2. Guru dapat menggunakan metode PP untuk menyampaikan materi termokimia agar siswa dapat memperoleh prestasi yang lebih baik. 3. pembelajaran materi termokimia sebaiknya memperhatikan kolaborasi antara faktor internal dengan metode pembelajaran

\section{Daftar Pustaka}

Afandi, Agus. (2012). Pembelajaran Kimia Menggunakan Metode RT untuk meningkatkan prestasi belajar siswa ditinjau dari Kemampuan berpikir kritis pada materi Biologi umum. publised Pendidikan Sains UNS. Surakarta.

Afifah, L. (2012). Efektivitas penggunaan model reciprocal teaching dengan melakukan fieldtrip terhadap hasil belajar matematika.

Ennis, R. H. (2011). The Nature of Critical Thinking: An Outline of Critical Thinking Dispositions, 1-8.

Fisher, Alec. 2009. Berpikir Kritis Sebuah Pengantar. Jakarta: Erlangga

Marsutji, E., Bakti, S., Sunarno, W., \& Suparmi. (2013). Dengan Laboratorium Riil Dan Laboratorium Virtuil Ditinjau Dari Kemampuan Berpikir. Inkuiri, 2(3), 238-246. Retrieved from http://jurnal.fkip.uns.ac.id/index.ph p/sains

Mcallum, R. (2014). Reciprocal Teaching: Critical Reflection on Practice. Weaving Educational Practice, 15(1), 26-35.

Nugroho, S., \& Mulyani, S. (2014). Pembelajaran Kimia Dengan model Thinking Aloudpair Problem Solving ( Tapps ) Dan Pp ( Pp ) Ditinjau Dari Kemampuan Verbal Dan kemampuan berpikir kreatif. Tesis, 1-11.

Nurkholis, A. (2013). Melalui Metode Eksperimen Dan Poe Ditinjau Dari Kemampuan Menggunakan Alat Ukur, 2(3), 216-227.

Nurlaila, N., Suparmi, \& Sunarno, W. (2013). Pembelajaran Fisika Dengan Pbl Menggunakan Problem Solving Dan Pp Ditinjau Dari Kreativitas Dan Keterampilan Berpikir. Inkuiiri, 2(2), 114-123.

Pittalis, M., Christou, C., Mousoulides, N., \& Pitta-Pantazi, D. (2004). A structural model for PP. Proceedings of the 28th ..., 4, 49- 
INKUIRI: Jurnal Pendidikan IPA

P-ISSN : 2252-7893

Vol. 8, No. 1, 2019 (hal 1-11)

E-ISSN: 2615-7489

https://jurnal.uns.ac.id/inkuiri

DOI: 10.20961/inkuiri.v8i1.31768

56. Retrieved from http://www. emis.ams.org/proceedings/PME28/ RR/RR058_Pittalis.pdf

Palinscar. A.S and A.L Brown. (1984). Rsiprocal Teaching of Comprehension Fostering and Comprehension Monitoring Activities. Cognition and Intruction. 2, 115-157.

Rosli, R., Capraro, M. M., \& Capraro, R. M. (2014). The Effects of PP on Student Mathematical Learning : A Meta-Analysis. JurnaInternational Education Studies;, 7(13), 227241.https://doi.org/10.5539/ies.v7n $13 \mathrm{p} 227$

Thompson, C. (2011). Critical Thinking Across the Curriculum. Humanities and Social Science, 1(9), 1-7. https://doi.org/10.1007/s11245-

016-9401-4 